\title{
Physical Activity, Food Consumption, and Breakfast among Normal and Overweight Elementary School Children in Bogor during Covid-19 Pandemic
}

\author{
Dini Rizkiani Putri, Cesilia Meti Dwiriani*, Dodik Briawan \\ Department of Community Nutrition, Faculty of Human Ecology, IPB University, Bogor 16680, Indonesia
}

\begin{abstract}
The objective of this study was to analyze differences in physical activity, quality of food consumption and breakfast between elementary school children with normal and overweight nutritional status in Bogor City of Indonesia during the Covid-19 pandemic. This was a cross sectional study carried out from September 2020 to January 2021 in nine elementary schools in Bogor City. This research was conducted when school from home had been running for about six months. Survey was conducted using a structured questionnaire filled by the subject's parents via google form and Microsoft word and then interviewing via whatsapp. Physical activity measured using the Physical Activity Level (PAL) method and food consumption quality using the Individual Dietary Diversity Score (IDDS). Breakfast quality based on the intake and contribution of energy and protein at breakfast. Result showed that $70 \%$ of male and $30 \%$ of female subjects were classified as overweight. There was a significant difference in the PAL value between subjects with normal weight and overweight ( 2.02 vs $1.63, p<0.05)$. There were no significant differences in IDDS of normal weight and overweight students in both weekday and weekend $(\mathrm{p}>0.05)$. However, IDDS scores of students with normal nutritional status was higher (7.08 and 8.60) compared to (6.80 and 6.78) in overweight students during the weekday and weekend respectively. In contrast, the energy and protein intake consumed during breakfast for overweight students was higher $(617 \mathrm{kcal} /$ day and $21 \mathrm{~g} /$ day) than students with normal nutritional status $(477 \mathrm{kcal} /$ day and $18.2 \mathrm{~g} /$ day $)$ $(p<0.05)$. This study has shown the importance to educate parents of overweight subjects to increase their children's physical activity as the students with normal nutrition status do as well as to provide breakfast with a more diverse menu.
\end{abstract}

Keywords: elementary school children, food consumption, overweight, physical activity

\section{INTRODUCTION}

Human capital is an important investment for the country growth and development this started since the early age. In addition to education, health and nutrition are also important contributors for improving the quality of future human resources. However, Indonesia is currently experiencing a triple burden of malnutrition, this encompasses the problem of under nutrition, micronutrient deficiencies and the problem of over-nutrition (overweight and obesity). Obesity is an increase fat mass either in certain parts or all parts of the body, or being overweight exceeds $20 \%$ of normal body weight (Mahan \& EscottStump 2008).

Based on data from the Ministry of Health Republic of Indonesia (MoH RI 2018) the problem of obesity in children aged 5-12 years in West Java was still high at $18.8 \%$, consisting of overweight $10.7 \%$ and obese $8.1 \%$. Meanwhile, the prevalence of overweight children aged 5-12 years in Bogor City was 17.2\%. Several factors that have been associated with obesity in children were sedentary lifestyle, unhealthy environment and food consumption. These factors can be seen at home, at school and in the community. The current Covid-19 pandemic accentuate this unhealthy environment. The sedentary lifestyle is characterized by decreased human movement, so that the level of physical activity and energy expenditure becomes lower. This lifestyle change was thought to be one of the triggering factors for increasing overweight and obesity (Oktaviani et al. 2012). Annisa (2014) shown that $78.8 \%$ of overweight students in Bogor City have light activities or sedentary lifestyle.

Indonesian usually eat several meals a day, this includes breakfast, lunch, dinner and snacking. The quality of food consume during

\footnotetext{
"Corresponding Author: tel: +6285312881466, email: cmdwiriani@apps.ipb.ac.id

(Received 07-07-2021; Accepted 03-09-2021; Published 29-11-2021)
} 
the meal time can be measured qualitatively by its diversity. Dewanti (2020) wrote that diversifying one's food consumption is an effort to meet their nutritional needs, because no single food contains all the nutrients. In addition, Retraningrum and Dieny (2015) showed that low quality in food consumption and lack of physical activity affect the obesity status of children and adolescents. Among all meals, breakfast was deemed as one of the most important meal for the day. Breakfast is an eating and drinking done in the morning until 9 a.m. to meet $15-30 \%$ of daily nutritional needs. Breakfast should meet 300-500 kcal and 6-10 g of protein (Hardinsyah \& Aries 2012). Milimet et al. (2010), stated that skipping breakfast can increase risk for weight gain by triggering eating more food during the day and at night. According to Mariza and Kusumastuti (2013) children's breakfast habits can affect children's snacking habits, where children who do not usually eat breakfast can increase the risk of snacking by 1.5 times. Students who skip breakfast tend to consume more snacks with higher calories.

Obese children have high risk of becoming obese as adults and have the potential to experience chronic non communicable diseases, including cardiovascular disease, hypertension, diabetes and others (Agustina et al. 2019). Based the background mentioned above, this research aimed to analyse differences in physical activity, quality of food consumption and breakfast between elementary school children with normal and overweight nutritional status in Bogor City during pandemic of Covid-19. The data was taken in Bogor City because the prevalence of overweight and obesity in children in the city were high. The context of Covid-19 pandemics adds a nuance to the data collection procedure as well as its analysis.

\section{METHODS}

\section{Design, location, and time}

This research was an analytic observational study utilizing a cross sectional design conducted from September 2020 to January 2021. The School from Home (SFH) policy has been running for six months when the data collection was started. The research was conducted online in nine elementary schools in Bogor City. The study had obtained permission and approval from the Research Ethics Commission of the Institute for
Research and Community Service (LPPM) IPB University with the number: 296/IT3.KEPMSM$\mathrm{IPB} / \mathrm{SK} / 2020$.

\section{Sampling}

The subjects of this study were students (grades four and five) with the age range of 10-11 years old from nine elementary schools (Sekolah Dasar) (SD) in Bogor city. The calculation of the minimum number of samples was based on to the proportion children with normal nutritional status and overweight with low physical activity which was $31.8 \%$ and $68.2 \%$ respectively, Rahma and Bambang (2020). The minimum number of subjects obtained was 38 children for each group. However, to anticipate drop out, the total number of participants was increased to 50 children with normal nutritional status and 50 children with overweight nutritional status (overweight and obesity). The sampling technique in this study was convenience sampling, Etikan et al. (2016) stated that convenience sampling is used for both qualitative and quantitative studies although it is most often used in quantitative studies. Convenience sampling is a type of nonrandom sampling in which members of the target population selected as sample are those who meet certain practical criteria such as easy accessibility, geographic proximity, availability at a certain time or willingness to participate.

Sampling selection was done through several steps, first is to obtain permission from the school principals. The principal then mandated the homeroom teacher to convey information related to the research to parents of students via WhatsApp messages. Parents who are willing to become respondents then join a special WhatsApp group for the research. The data collection was done consecutively one school at the time. Each school gets a different number of respondents. The number of respondents in each school are as follow: SD Insan Kamil six people (four normal nutritional status and three overweight), SD Sinar Indonesia two people (one normal nutritional status and one overweight), SD Bina Bangsa Sejahtera 11 people (eight normal nutritional status and three overweight), SD Al-Mustarih 20 people (eight normal nutritional status and 12 overweight), SD Bosowa Bina Insani 19 people (13 normal nutritional status and six overweight), SD Aliya 17 people (eight normal nutritional status and nine overweight), SD Al-Munawwar 
five people (three normal nutritional status and two overweight), SD IT-ABN 12 people (six normal nutritional status and six overweight), and SD Insantama eight people (0 normal nutritional status and eight overweight). The total subjects participated in this study were 100 people.

\section{Data collection}

The data collection method was adapted to the School from Home (SFH) condition. During the Covid-19 pandemic, the school and parents did not give permission for researchers to meet at home or at school. Therefore, the measurements of height and weight were carried out by parents at their respective homes. Weight was measured using home scale and height was measured using measuring tape. Subject were group based on the anthropometric screening results of weight and height to obtain their Body Mass Index (BMI). The nutritional status group was seen based on the BMI's Z-score. Subjects who had z-score value of $-2 S D$ to $+1 S D$ are included in the normal nutritional status group. Subjects who had $z$-score value of $+1 \mathrm{SD}$ to $+2 \mathrm{SD}$ and $>+2 \mathrm{SD}$ are included in overweight nutritional status group (Permenkes RI 2020).

The data on subjects' characteristics, physical activity and food consumption were filled out by parents through a questionnaire in google form and Microsoft Word, then a follow up interview was conducted by phone. The children did not fill out any of the questionnaire because measurements and questionnaire filled by mothers were considered as more valid, since mothers were responsible for providing food for their children every day.

Data on physical activity collected includes the type of activity and the time allocation for each activity. Physical activity data consisted of the average physical activity on weekday and weekends. Physical activity was expressed in terms of physical activity level or Physical Activity Level (PAL). PAL is the amount of energy expended (kcal) per kilogram of body weight in 24 hours. PAR (Physical Activity Rate) was the amount of energy expended for a certain type of activity per unit of time. PAR values differ from one activity to another. PAL was calculated by the total multiplication formula of PAR with the time allocation for each activity then divided by 24 hours. Physical Activity Level (PAL) was categorized into four, namely: very light (PAL $\leq 1.39$ ); light (PAL 1.40-1.69); moderate (PAL 1.70-1.99); and heavy (PAL 2.00-2.40) (FAO/ WHO/UNU 2001).

Food consumption data was obtained through $2 \times 24$ hours food recalls on weekday and weekend which then translated into Individual Dietary Diversity Score (IDDS). The diversity of food consumption was calculated based on nine food groups, namely starchy staple foods; green vegetable; fruit and vegetable sources of vitamin A; fruit and vegetables and others; innards; meat. fish and chicken; egg; pods, beans, and seeds; and milk and its processed products. Any food group consumed for $\geq 10 \mathrm{~g}$ was assigned a score of one, while score of zero was assigned for consumption of less than $10 \mathrm{~g}$. Kennedy et al. (2007) dietary diversity based on IDDS can be grouped into three categories, namely low diversity ( $\leq 3$ types of food groups/day), moderate diversity (4-5 types of food groups/day) and high diversity ( $\geq 6$ types of food groups/day). Data regarding calorie contribution from breakfast were obtained from food record in a week.

\section{Data analysis}

Data processing and analysis was carried out using Microsoft Excel 2017 and SPSS version 17.0 for Windows. Associations between the children's nutritional status with categorical variables were tested using chi-square test. Kolmogrov Smirnov test was used to check for normality. Independent sample t-test was used for data with normal distribution. While, Mann-Whitney test was used for non-normally distributed data.

\section{RESULTS AND DISCUSSION}

\section{Characteristics of subjects}

Table 1 showed that there were significant differences between the gender of normal and overweight subjects $(\mathrm{p}<0.05)$ with more male $(70 \%)$ were overweight compared to female $(30 \%)$. A study among elementary school children in Banda Aceh by Rahmad's (2019) showed that there were more female $(59.5 \%)$ with obesity compared to male $(40.5 \%)$. However, it should bear in mind that this study focused on overweight rather than obesity and used convenience sampling. As shown in Table 1 , there was no significant difference in the age of subjects with normal nutritional status and 
Table 1. Characteristics of subjects based on nutritional status

\begin{tabular}{lccc}
\hline $\begin{array}{c}\text { Characteristics of } \\
\text { subjects }\end{array}$ & $\begin{array}{c}\text { Normal } \\
(\mathrm{n}=50)\end{array}$ & $\begin{array}{c}\text { Overweight } \\
(\mathrm{n}=50)\end{array}$ & $\mathrm{n}(\%)$ \\
\cline { 2 - 3 } Sex & & & \\
Male & $26(52.0)$ & $35(70.0)$ & \\
Female & $24(48.0)$ & $15(30.0)$ & $0.033^{*}$ \\
Age (years old) & & & \\
10 & $36(72.0)$ & $35(70.0)$ & \\
11 & $12(24.0)$ & $15(30.0)$ & 0.155 \\
12 & $2(4.0)$ & $0(0.0)$ & \\
Allowance (IDR/day) & & & \\
<IDR10,000 & $1(2.0)$ & $3(6.0)$ & \\
IDR10,000-19,999 & $46(92.0)$ & $45(90.0)$ & 0.273 \\
$\geq$ IDR20,000 & $3(6.0)$ & $2(4.0)$ & \\
\hline
\end{tabular}

Chi-square test; ${ }^{*}$ Significance $\mathrm{p}<0.05$

IDR: Indonesian Rupiah

overweight nutritional status $(\mathrm{p}>0.05)$. Most of the subjects were ten years old, both in normal subjects $(72.0 \%)$ and overweight subjects (70.0\%). According to Ermona and Wirjatmadi (2018), children at the age of ten both boys and girls, have an appetite that tends to increase during their growth period towards adolescence. The results showed that there was no significant difference between the daily allowances of normal and overweight subjects $(\mathrm{p}>0.05)$. The majority of the normal subjects $(92.0 \%)$ and overweight subjects $(90.0 \%)$ were given pocket money of IDR10,000-IDR19,999 per day. According to Faghih et al. (2015) children who get a larger amount of pocket money tend to consume fast food more often which lead to unhealthy lifestyle as one of the factors causing obesity.

\section{Physical activity}

Physical activity was body movement characterized by the work of skeletal muscles and increased energy and energy expenditure (MoH RI 2018). Table 2 showed the average of activity duration between normal and overweight subjects on weekday and weekend during the Covid-19 pandemic.
Table 2 showed that there were significant differences in duration of sleep, personal activity, online learning, playing and light activity between normal and overweight subjects $(p<0.05)$. Overweight subjects had significantly longer duration of sleep, online learning and light activities (except for playing Lego) compared with normal subject. While, normal subject had significantly longer duration of personal activity and playing than overweight subjects. Na'imah's research (2014) showed that subjects who got enough sleep (7-9 hours a day) tended to have a normal body mass index compared to subjects who have less sleep duration ( $<7$ hours a day).

Spaeth et al. (2019) stated that less sleep is associated with higher Body Mass Index (BMI). Sleep problems can affect the body's hormones and metabolism. In addition, Muscogiuri et al. (2019) found that increased intake of unhealthy food consumption occurs when hormones and metabolism were in abnormal conditions and it can trigger weight gain.

The average duration of watching TV and playing gadgets was significantly longer in overweight subjects than normal subject. The average screen time for both groups during the Covid-19 pandemic was more than two hours per day. In contrast, Xiang et al. (2020) found that before Covid-19 pandemic about $92.7 \%$ of children and adolescents in China had screen time duration of two hours per day or less while only $7.3 \%$ had screen time duration of more than two hours per day. American Academy of Pediatrics (AAP) (2001) stated that Low Screen Time (LST) is a screen time with a duration of $<2$ hours per day and High Screen Time (HST) with a duration of two hours per day. Chassiakos et al. (2016) also recommends screen time duration for children and adolescents as much as two hours per day.

Screen time viewing was one of the external factors that influence diet trough exposure to and promotion of unhealthy diets and lifestyle. Tarabashkina et al. (2016) stated that screen time can cause higher energy intake, one of which was caused by exposure to food and beverage advertisements that are widely offered on television. The products offered in advertisements are generally foods that contain high energy. Children exposed to advertisements tend to consume the advertised food so that they have a higher energy intake than children who 


\section{Physical activities and food consumption of children}

Table 2. The differences of activity duration between normal and overweight subjects

\begin{tabular}{lccc}
\hline \multicolumn{1}{c}{ Activities } & Normal (hours) & Overweight (hours) & $\mathrm{p}$ \\
\hline Sleep & $8.85 \pm 0.18$ & $9.71 \pm 0.50$ & $0.000^{1^{*}}$ \\
Personal & $2.89 \pm 0.11$ & $2.66 \pm 0.13$ & $0.000^{1^{*}}$ \\
Praying & $1.64 \pm 0.11$ & $1.40 \pm 0.13$ & $0.000^{1^{*}}$ \\
Take a bath & $0.50 \pm 0.00$ & $0.51 \pm 0.03$ & $0.047^{1^{*}}$ \\
Eat & $0.75 \pm 0.00$ & $0.75 \pm 0.00$ & $0.500^{1}$ \\
Online learning & $2.64 \pm 0.31$ & $3.34 \pm 0.60$ & $0.000^{1^{*}}$ \\
Carry out task & $0.89 \pm 0.31$ & $1.59 \pm 0.60$ & $0.000^{1^{*}}$ \\
School from home & $1.75 \pm 0.00$ & $1.75 \pm 0.00$ & $0.500^{1}$ \\
Playing & $5.00 \pm 0.67$ & $1.89 \pm 0.60$ & $0.000^{1^{*}}$ \\
Cycling & $2.09 \pm 0.47$ & $0.93 \pm 0.50$ & $0.000^{2^{*}}$ \\
Badminton & $0.43 \pm 0.35$ & $0.03 \pm 0.12$ & $0.000^{1^{*}}$ \\
Football & $0.51 \pm 0.59$ & $0.15 \pm 0.25$ & $0.001^{1^{*}}$ \\
Ping pong & $0.57 \pm 0.50$ & $0.27 \pm 0.31$ & $0.001^{1^{*}}$ \\
Jumping rope & $0.21 \pm 0.38$ & $0.02 \pm 0.07$ & $0.001^{1^{*}}$ \\
Hide and seek & $1.19 \pm 0.56$ & $0.49 \pm 0.33$ & $0.000^{1^{*}}$ \\
Light activity & $4.62 \pm 0.53$ & $6.40 \pm 0.78$ & $0.000^{2^{*}}$ \\
Watching television & $2.16 \pm 0.50$ & $3.53 \pm 0.75$ & $0.000^{2^{*}}$ \\
Playing gadget & $1.26 \pm 0.42$ & $2.15 \pm 0.56$ & $0.000^{2^{*}}$ \\
Playing lego & $1.20 \pm 0.76$ & $0.72 \pm 10.76$ & $0.001^{2^{*}}$ \\
\hline
\end{tabular}

${ }^{1}$ Mann-whitney test; ${ }^{2}$ Independent sample t-test; ${ }^{*}$ Significance $\mathrm{p}<0.05$

were not exposed to advertisements. Children and adolescents consumed foods which was high in sugar, salt, fat, calories and carbonated drinks (Wardlaw \& Hampl 2007). According to Pinho et al. (2017) poor diet can increase BMI and causing obesity. In addition, longer screen time mean less time for physical activity and sedentary behavior in adolescents was one of the risk factors that can cause obesity. Further, Laurson et al. (2014) stated that screen time can cause sleep disturbances. This was caused by the presence of artificial light from the screen so that it interferes with the hormonal response. Decreased sleep time, one of which is caused by artificial light from excessive screen time, thereby increasing sleep deprivation and increasing energy intake. According to Bel et al. (2013) adolescents who sleep less than eight hours have higher fat intake, consumption of foods high in energy content and low quality of diet (foods with high energy density and low nutrient content) when compared to adolescents who sleep $\geq 8$ hours a day. During pandemic of Covid-19, subject distribution based on their physical activity level can be seen in Table 3.

Table 3 shows that there was significant difference in physical activity between normal and overweight subjects $(\mathrm{p}=0.000)$. During the Covid-19 pandemic, $64.0 \%$ of normal subjects had heavy physical activity with PAL value of 2.02. While on the other hand, most of the overweight subjects $(90.0 \%)$ had light physical activity with PAL value of 1.63 . The results showed that during pandemic of Covid-19, normal subject had better physical activity than overweight subject. Similarly, Rizkiyah (2015) showed that normal subjects had higher PAL value than overweight subject, despite both groups were classified as having light physical activity. In addition, Jiménez-Pavón (2010), also found that children with low physical activity levels had higher Body Mass Index than normal and had greater chance of experiencing more nutritional problems. Colley et al. (2013), 
Table 3. Subject distribution based on physical activity

\begin{tabular}{lcccccc}
\hline \multirow{2}{*}{ Physical activity level (PAL) } & \multicolumn{2}{c}{ Normal } & \multicolumn{2}{c}{ Overweight } & \multicolumn{2}{c}{ Total } \\
\cline { 2 - 7 } & $\mathrm{n}$ & $\%$ & $\mathrm{n}$ & $\%$ & $\mathrm{n}$ & $\%$ \\
\hline Very low ( $\leq 1.39)$ & 0 & 0.0 & 0 & 0.0 & 0 & 0.0 \\
Low $(1.40-1.69)$ & 0 & 0.0 & 45 & 90.0 & 45 & 45.0 \\
Moderate (1.70-1.99) & 18 & 36.0 & 5 & 10.0 & 24 & 24.0 \\
Severe (2.00-2.40) & 32 & 64.0 & 0 & 0.0 & 31 & 31.0 \\
\hline
\end{tabular}

showed that physical activity was associated with the incidence of over-nutrition in children. This happens because of an imbalance between energy intake and energy released from the body.

\section{Quality of food consumption}

Table 4 showed the difference in the average score of each food groups consumed based on the IDDS for normal and overweight subjects on school days (weekday). While Table 5 showed the same information for weekend. Children from the normal weight group had a significantly higher average scores in consumption of Vitamin A source fruit and vegetable and other fruits and vegetables $(p<0.05)$. The average score of fruit and vegetable sources of vitamin A was 0.92 food groups/day in children with normal weight and 0.80 food groups/day in the overweight group. Normal subject had an average score of 0.98 food groups/day for other fruits and vegetables while the overweight group was 0.84 food groups/ day. This implies that, more students in the normal weight group consumed vitamin A source fruits and vegetables as well as other fruits and vegetables. However, there was no difference in the total score of IDDS between normal and overweight subjects $(\mathrm{p}=0.227)$ and both groups had a high IDDS based on Kennedy et al. (2007) since both groups consumed more than 6 types of food groups/day. The average IDDS for children in the normal weight group was 7.08 (SD 1.96) while in the overweight group was 6.80 (SD 2.75).

In contrast to the IDDS during the weekday, on the weekend the consumption of fruits and vegetables and vitamin A source food showed no significant difference in both groups. The total IDDS also showed no significant difference between the two groups. The IDDS average score in the group with normal weight was 8.60 (SD 5.95) food groups/day or higher compared to the weekday, and among the overweight it was 6.78 (SD 2.73) food groups/day or almost the same as the weekday. This showed that during the weekend, children with normal weight tend to eat more food groups.

Table 4. The difference of average score for diversity of food consumption in normal and overweight subjects based on food groups during weekday

\begin{tabular}{lccc}
\hline \multirow{2}{*}{\multicolumn{1}{c}{ Food group }} & \multicolumn{2}{c}{ Individual dietary diversity score } & \multirow{2}{*}{$\mathrm{p}$} \\
\cline { 2 - 3 } & Normal (Mean \pm SD) & Overweight (Mean \pm SD) & \\
\hline Starchy staple food & $1.00 \pm 0.00$ & $1.00 \pm 0.00$ & 0.500 \\
Green vegetable & $0.90 \pm 0.30$ & $0.90 \pm 0.30$ & 0.500 \\
Fruits and vegetables sources of vitamin A & $0.92 \pm 0.27$ & $0.80 \pm 0.40$ & $0.043^{*}$ \\
Other fruits and vegetables & $0.98 \pm 0.14$ & $0.84 \pm 0.37$ & $0.008^{*}$ \\
Innards & $0.00 \pm 0.00$ & $0.04 \pm 0.20$ & 0.078 \\
Meat, fish, and poultry & $1.00 \pm 0.00$ & $0.96 \pm 0.20$ & 0.078 \\
Egg & $0.62 \pm 0.49$ & $0.66 \pm 0.48$ & 0.266 \\
Pod, peanuts, grains & $0.80 \pm 0.40$ & $0.74 \pm 0.44$ & 0.239 \\
Milk and processed products & $0.86 \pm 0.35$ & $0.86 \pm 0.35$ & 0.500 \\
Individual dietary diversity score (IDDS) & $7.08 \pm 1.96$ & $6.80 \pm 2.75$ & 0.227 \\
\hline
\end{tabular}

Mann-whitney test; ${ }^{*}$ Significance $\mathrm{p}<0.05$ 


\section{Physical activities and food consumption of children}

Table 5 . The difference of dietary diversity score between normal and overweight subjects based on food groups during weekend

\begin{tabular}{lccc}
\hline \multirow{2}{*}{\multicolumn{1}{c}{ Food group }} & \multicolumn{2}{c}{ Individual dietary diversity score (IDDS) } & \multirow{2}{*}{$\mathrm{p}$} \\
\cline { 2 - 3 } & Normal (Mean \pm SD) & Overweight (Mean \pm SD) & \\
\hline Starchy staple food & $1.00 \pm 0.00$ & $1.00 \pm 0.00$ & 0.500 \\
Green vegetable & $0.92 \pm 0.27$ & $0.90 \pm 0.30$ & 0.364 \\
Fruits and vegetables sources of vitamin A & $0.90 \pm 0.30$ & $0.90 \pm 0.30$ & 0.500 \\
Other fruits and vegetables & $0.80 \pm 0.40$ & $0.86 \pm 0.35$ & 0.214 \\
Innards & $0.06 \pm 0.24$ & $0.08 \pm 0.27$ & 0.349 \\
Meat, fish, and poultry & $1.00 \pm 0.00$ & $0.98 \pm 0.14$ & 0.159 \\
Egg & $0.54 \pm 0.50$ & $0.56 \pm 0.50$ & 0.421 \\
Pod, peanuts, grains & $0.86 \pm 0.35$ & $0.82 \pm 0.39$ & 0.294 \\
Milk and processed products milk & $0.70 \pm 0.46$ & $0.68 \pm 0.47$ & 0.415 \\
Individual dietary diversity score (IDDS) & $8.60 \pm 5.95$ & $6.78 \pm 2.73$ & 0.468 \\
\hline
\end{tabular}

Mann-whitney test; ${ }^{*}$ Significance $\mathrm{p}<0.05$

The study of Swamilaksita and Sa'pang (2018) showed that there was no significant difference in IDDS in children with normal nutritional status and obesity $(\mathrm{p}=0.791)$. However, in their study the mean IDDS was very low at only 1.5 (SD 0.5) food groups/day. The food groups most consumed by school children in West Jakarta in the study are sources of carbohydrates (bread, rice, potatoes), sources of animal protein (sausage, eggs, chicken), and sources of vegetable protein (tempe, green beans, tofu). Similarly, Nurrachmat (2016) also found no significant difference in the diversity of food consumption between normal and obese school children $(p=0.705)$ with the average IDDS of five food groups/day in children with normal weight and 4.89 food groups/day in children with obesity. The most common food groups consumed in the study were starchy staple foods; meat, fish, chicken; and eggs.

\section{Breakfast quality}

Table 6 showed the intake and contribution of energy and protein from breakfast for normal weight and overweight subjects. The energy intake from breakfast for overweight subjects (617 kcal) was greater than normal subjects (477 kcal). Protein intake for overweight subjects (21 g) was higher than normal subjects $(18.2$ g). According to Hardinsyah (2012) breakfast fulfills about $15-25 \%$ of daily nutritional needs. Breakfast energy intake should meet 300-500

Table 6. Differences energy and protein intake from breakfast between normal and overweight subjects

\begin{tabular}{lccc}
\hline \multicolumn{1}{c}{ Energy and Protein } & Normal & Overweight & \multirow{2}{*}{$\mathrm{p}^{1}$} \\
\cline { 2 - 3 } & \multicolumn{2}{c}{ Mean \pm SD } \\
\hline Energy & $477 \pm 71.7$ & $617 \pm 140.1$ & $0.000^{*}$ \\
$\quad$ Intake (kcal/day) & $28.4 \pm 3.3$ & $27.6 \pm 4.1$ & 0.157 \\
$\quad$ Contribution to daily intake (\%) & $29.9 \pm 6.3$ & $31.3 \pm 6.9$ & 0.153 \\
$\quad$ Contribution to energy adequacy (\%) & & & \\
Protein & $18.2 \pm 2.8$ & $21.0 \pm 3.9$ & $0.000^{*}$ \\
$\quad$ Intake (g/day) & $30.5 \pm 6.6$ & $28.6 \pm 5.8$ & 0.067 \\
$\quad$ Contribution to daily intake (\%) & $41.0 \pm 8.4$ & $42.4 \pm 8.3$ & 0.199 \\
$\quad$ Contribution to protein adequacy (\%) & & & \\
\hline
\end{tabular}

${ }^{1}$ Independent sampel t-test; ${ }^{*}$ Significance $\mathrm{p}<0.05$ 
$\mathrm{kcal} /$ day and protein intake $6-10 \mathrm{~g} / \mathrm{day}$. Thus, results showed that energy intake from breakfast for children with normal weight was within the recommended range, while for the overweight subjects it exceeded the recommended range. On the other hand, the protein intake from breakfast in children in both groups exceeded the recommended limit.

Table 6 showed that during pandemic of Covid-19, there was no difference in the contribution of energy to daily intake and energy adequacy in the two groups of subjects ( $>0.05)$. Likewise, there was no difference in the contribution of protein to daily intake and protein adequacy in the two groups of subjects ( $>0.05)$. In normal subjects, breakfast contributed energy and protein to the daily intake greater than the overweight subjects. In normal subjects, the contribution of breakfast contributed energy and protein to nutritional adequacy was greater than the overweight subjects. The results of the study were in accordance with Ifdal (2014), who found that among university students the energy intake from breakfast in overweigh subject (425 $\mathrm{kcal} /$ day) was greater than normal subject (365 $\mathrm{kcal} /$ day). The protein intake from breakfast of overweight subject $(10.1 \mathrm{~g} /$ day $)$ was greater than normal subject (9.6 g/day). A study on school children in Banda Aceh showed that 59.5\% of obese school children had a poor breakfast intake. Breakfast intake is considered inadequate if it contributes less than $200-300 \mathrm{kcal} /$ day or more than $200-300 \mathrm{kcal} /$ day. In the study, more than half $(57.1 \%)$ of school children with normal nutritional status had adequate breakfast intake of around 200-300 kcal/day (Rahmad 2019). Our study found that the intake of energy and protein was higher among our subjects during the pandemic compared to previous study, this might be because children are more likely to consume staple food, meat, fish and poultry than fruits and vegetables during this time.

The was conducted during the Covid-19 pandemic, which has not been widely carried out. Process of calculating the difference in the duration of each activity carried out by the subject as well as the quality of food consumption using the IDDS method. This can indirectly educate parents and increase their awareness on the importance of physical activity and dietary diversity for their children. However, due to the mobility restriction during the Covid-19 pandemic, the anthropometry measurement of the subject's weight and height was not carried out by the researcher and the subject population only came from private schools due to the use of convenience sampling method.

\section{CONCLUSION}

In this study found more male subjects with overweight status than female. During pandemic of Covid-19, subjects with normal nutritional status had higher level of physical activity (PAL 2.02) than subjects with overweight nutritional status (PAL 1.63). Overall, the total score of diversity from normal subject was higher than of overweight subject (weekday $=7.08$; weekend $=8.60$ ). The intake of energy and protein from breakfast was significantly higher in overweight subject $(617 \mathrm{kcal}$ energy and protein $21 \mathrm{~g} /$ day) than in normal subject ( $477 \mathrm{kcal}$ energy and $18.2 \mathrm{~g}$ protein/day). Recommendations for further research, to improve sampling method to cover more diverse demography, to get more valid results it is better to measure height and weight directly by researchers and measure breakfast quality based on macronutrients (energy, protein, fat, and carbohydrates).

\section{ACKNOWLEDGEMENT}

The authors wish to thank the SD Insan Kamil, SD Sinar Indonesia, SD Bina Bangsa Sejahtera, SD Al-Mustarih, SD Bosowa Bina Insani, SD Aliya, SD Al-Munawwar, SD IT-ABN, and SD Insantama in Bogor city for permission to carry out the research. Appreciation is also given to the parents and students who have participated in this research.

\section{DECLARATION OF INTERESTS}

The authors have no conflict of interest.

\section{REFERENCES}

[AAP] American Academy of Pediatrics. 2001. Children, adolescents, and television. Pediatrics 107(2):423-426. https://doi. org/10.1542/peds.107.2.423

Agustina L, Maas LT, Zulfendri Z. 2019. Analisis faktor perilaku berisiko terhadap kejadian obesitas pada anak usia 9-12 tahun di 


\section{Physical activities and food consumption of children}

SD Harapan 1 Medan. J Endurance 4(2):371-381. https://doi.org/10.22216/ jen.v4i2.4051

Annisa DT. 2014. Asupan energi, zat gizi, dan serat serta aktivitas fisik siswa sekolah dasar berstatus gizi lebih di Kota Bogor [Undergraduate Thesis]. Bogor: IPB University.

Bel S, Michels N, Vriendt TD, Patterson E, Cuenca-Garcia M, Diethelm k, Gutin B, Grammatikaki E, Manios Y, Leclercq C et al. 2013. Association between selfreported sleep duration and dietary quality in European adolescents. Br j Nutr 110(5):949-959. https://doi.org/10.1017/ S0007114512006046

Chassiakos YLR, Radesky J, Christakis D, Moreno MA, Cross C. 2016. Children and adolescent and digital media. Pediatrics 138(5):1-18. https://doi.org/10.1542/ peds.2016-2593

Colley RC, Garriguet D, Adamo KB, Carson V, Janssen I, Timmons BW, Trembly MS. 2013. Physical activity and sedentary behaviour during the early years in Canada: A cross-sectional study. Int $\mathrm{J}$ Behav Nutr Phys Act 10(54):1-9. https:// doi.org/10.1186/1479-5868-10-54

Dewanti S. 2020. Keragaman konsumsi pangan rumah tangga di Provinsi Jawa Tengah. Jurnal Kawistara 10(3):265-294. https:// doi.org/10.22146/kawistara.46787

Ermona ND, Wirjatmadi B. 2018. Hubungan aktivitas fisik dan asupan gizi dengan status gizi lebih pada anak usia sekolah dasar di SDN Ketabang 1 Kota Surabaya tahun 2017. Amerta Nutrition 2(1):97$105 . \quad$ https://doi.org/10.20473/amnt. v2i1.2018.97-105

Etikan I, Musa SA, Alkassim RS. 2016. Comparison of convenience sampling and purposive sampling. American Journal Theoretical and Applied Statistics 5(1):1-4. https://doi.org/10.11648/j. ajtas.20160501.11

[FAO/WHO/UNU] Food Agriculture Organization/World Health Organization/ United Nation University. 2001. Human Energi Requirement: Report of a Joint FAO/WHO/UNU. Rome (IT): FAO.

Faghih S, Keshani P, Salar A, Rajaei SH, Mirzaei Z, Moosavi SM, Hematdar Z.
2015. Assessment of obesity, unhealthy food habits, and nutritional knowledge of primary school children. Int J Sch Health 2(2):1-5. https://doi.org/10.17795/ intjsh-25186

Hardinsyah H, Aries M. 2012. Jenis pangan sarapan dan peranannya dalam asupan gizi harian anak usia 6-12 tahun di Indonesia. J Gizi Pangan 7(2):89-96. https://doi. org/10.25182/jgp.2012.7.2.89-96

Ifdal. 2014. Kebiasaan sarapan pada mahasiswa TPB IPB dengan status gizi normal dan obes [Undergraduate Thesis]. Bogor: IPB University.

Jiménez-Pavón D, Kelly J. Reilly JJ. 2010. Associations between objectively measured habitual physical activity and diposity in children and adolescent: Systematic review. Int J Pediatr Obes 5(1):3-18. https://doi. org/10.3109/17477160903067601

Kennedy GL, Pedro MR, Seghieri C, Nantel G, Brouwer I. 2007. Dietary diversity score is a useful indicator of micronutrient intake in non-breast-feeding filipino children. J Nutr 137(2):472-477. https://doi.org/10.1093/ jn/137.2.472

Laurson KR, Lee JA, Gentile DA, Walsh DA, Eisenmann JC. 2014. Concurrent associations between physical activity, screen time, and sleep duration with childhood obesity. Int Sch Res Notices 1-6. https://doi.org/10.1155/2014/204540

[MoH RI] Ministry of Health Republic of Indonesia. 2018. Riset Kesehatan Dasar. Jakarta (ID): MoH RI.

Mahan LK, Escott-Stump S. 2008. Krause's Food, Nutrition, and Diet Therapy. St. Louis (USA): W.B Saunders Company.

Mariza YY, Kusumastuti AC. 2013. Hubungan antara kebiasaan sarapan dan kebiasaan jajan dengan status gizi anak sekolah dasar di Kecamatan Pedurungan Kota Semarang. J Nutr Coll 2(1):207-213. https://doi. org/10.14710/jnc.v2i1.2108

Millimet DL, Tchernis R, Husain M. 2010. School nutrition programs and the incidence of childhood obesity. J Hum Resour 45(3):640-654. https://doi.org/10.1353/ jhr.2010.0021

Muscogiuri G, Barrea L, Annunziata G, Di Somma C, Laudisio D, Colao A, Savastano S. 2019. Obesity and sleep disturbance: 
The chicken or the egg? Crit Rev Food Sci Nutr 59(13):2158-2165. https://doi.org/10 .1080/10408398.2018.1506979

Na'imah F. 2014. Hubungan kebiasaan tidur dan menonton televisi dengan status gizi remaja di SMP Bina Insani Bogor. [Undergraduate Thesis]. Bogor: IPB University.

Nurrachmat MFF. 2016. Hubungan antara sosial ekonomi keluarga dengan keragaman konsumsi pangan dan kegemukan pada anak sekolah dasar [Undergraduate Thesis]. Bogor: IPB University.

Oktaviani WD, Saraswati LD, Rahfiludin MZ. 2012. Hubungan kebiasaan konsumsi fast food. aktivitas fisik. pola konsumsi. karakteristik remaja dan orang tua dengan indeks massa tubuh (IMT) (studi kasus pada siswa SMA Negeri 9 Semarang tahun 2012). Jurnal Kesehatan Masyarakat 1(2):542-553.

[Permenkes RI] Peraturan Menteri Kesehatan RI. 2020. Peraturan Menteri Kesehatan RI Nomor 2 Tahun 2020 tentang Standar Antropometri Anak. Jakarta (ID): Permenkes RI.

Pinho MGMD, Adami F, Benedet J, Vasconcelos FDAGD. 2017. Association between screen time and dietary patterns and overweight. Rev de Nutr 30(3):377-389. https://doi. org/10.1590/1678-98652017000300010

Rahma EN, Bambang W. 2020. Hubungan antara aktivitas fisik dan aktivitas sedentary dengan status gizi lebih pada anak sekolah dasar. Amerta Nutrition 4(1):79-84. https:// doi.org/10.20473/amnt.v4i1.2020.79-84

Rahmad AHA. 2019. Keterkaitan asupan makanan dan sedentary dengan kejadian obesitas pada anak sekolah dasar di Kota Banda Aceh. Buletin Penelitian Kesehatan.
47(1):67-76. https://doi.org/10.22435/ bpk.v47i1.579

Retraningrum G, Dieny FF. 2015. Kualitas konsumsi dan aktivitas fisik pada remaja obesitas dan non obesitas [Undergraduate Thesis]. Semarang: Universitas Diponegoro.

Rizkiyah R. 2015. Kebiasaan makan. aktivitas fisik. dan kebugaran pada anak sekolah dasar dengan status gizi normal dan lebih di Kota Bogor [Undergraduated Thesis]. Bogor: IPB University.

Spaeth AM, Hawley NL, Raynor HA, Jelalian E, Greer A, Crouter SE, Coffman DL, Carskadon MA, Owens JA, Wing RR et al. 2019. Sleep, energy balance, and meal timing in school-aged children. Sleep Med 60:139-144. https://doi.org/10.1016/j. sleep.2019.02.003

Swamilaksita PD, Sa'pang M. 2018. Keragaman konsumsi pangan dan densitas gizi pada remaja obesitas dan non obesitas. Nutr Diaita 9(2):44-50. https://doi. org/10.47007/nut.v9i02.2199

Tarabashkina L, Quester P, Crouch R. 2016. Food advertising, children's food choices and obesity, interplay of cognitive defences and product evaluation: An experimental study. Int J Obes 40(4):581-586. https:// doi.org/10.1038/ijo.2015.234

Wardlaw GM, Hampl JS. 2007. Perspectives in Nutrition. New York (USA): McGraw-Hill Higher Education.

Xiang M, Zhang Z, Kuwahara K. 2020. Impact of COVID-19 pandemic on children and adolescents' lifestyle behavior larger than expected. Prog Cardiovasc Dis 63(4):531-532. https://doi.org/10.1016/j. pcad.2020.04.013 